\title{
A Study on Unusual Foramen in the Middle Cranial Fossa in Adult South Indian Dry Skulls
}

\author{
Danisca. U', Thenmozhi. M. S ${ }^{2}$ and Yuvaraj Babu. $\mathrm{K}^{3}$ \\ ${ }^{1}$ Department of Anatomy Saveetha Dental College and hospital, Saveetha \\ Institute of Medical and Technical Sciences, Chennai - 600077, India. \\ ${ }^{2}$ Department of Anatomy Saveetha Dental College and hospitals, Saveetha Institute \\ of Medical and Technical Sciences, Saveetha University, Chennai - 600077, India \\ ${ }^{3}$ Department of Anatomy, Saveetha Dental College and Hospitals, Saveetha Institute of \\ Medical and Technical Sciences, Saveetha University, Chennai - 600077 India
}

\section{ABSTRACT}

Foramen Vesalius is present in anteromedial side of the foramen ovale. It connects the pterygoid plexus with the cavernous sinus and transmits a small emissary vein which drains the cavernous sinus. The main importance of this foramen is that it offers a path for the spread of an infection from the extracranial source to the cavernous sinus. Foramen innominatus is found between foramen spinosum and foramen ovale if present it transmits the lesser petrosal nerve. Neurosurgeons should be very precautious about these unusual foramina.The main aim of this study is to analyse the presence of foramen vesalius and foramen innominatus in the middle cranial fossa. For the present study,30 dry human cranial fossa of unknown sex from the Department of Anatomy, Saveetha Dental College and Hospitals, Chennai was examined. From the study, the incidence of unusual foramina was 23.3\%. Foramen vesalius was present in $10 \%$ of the total skulls and foramen innominatus was present in 13.3\% of the total skulls studied. Knowledge about this unusual foramina will be useful for neurosurgeons while conducting surgeries.

\section{KEY WORDS: CAVERNOUS SINUS, FORAMEN INNOMINATUS, FORAMEN VESALIUS, MIDDLE CRANIAL FOSSA.}

\section{INTRODUCTION}

This study deals with the unusual foramina present in the middle cranial fossa . Foramina are the openings that are present in the base of the skulls that allow passage of important structures such as nerves and blood vessels. The greater wing of the sphenoid contains three consistent foramina and other small variable foramina. The consistent foramina are the foramen rotundum, foramen

\section{ARTICLE INFORMATION}

*Corresponding Author: yuvarajbabu@saveetha.com Received 7th August 2020 Accepted after revision 27th Sep 2020 Print ISSN: 0974-6455 Online ISSN: 2321-4007 CODEN: BBRCBA

Thomson Reuters ISI Web of Science Clarivate Analytics USA and Crossref Indexed Journal

\section{Clarivate
Analytics}

NAAS Journal Score 2020 (4.31) SJIF: 2020 (7.728)

A Society of Science and Nature Publication,

Bhopal India 2020. All rights reserved.

Online Contents Available at: http//www.bbrc.in/

Doi: http://dx.doi.org/10.21786/bbrc/13.8/118 ovale and foramen spinosum, accessory foramina includes foramen vesalius and foramen innominatus, these are present close to foramen ovale (Raval, Singh and Rajguru, 2015). Foramen vesalius connects the pterygoid plexus with cavernous sinus. The importance of this foramen is that it provides a path for infections to spread from the extracranial source to the cavernous sinus (Kumar, Sehgal and Roy, 2016). This foramen is also called as the emissary sphenoidal foramen.

The emissary sphenoidal foramen differs in size among different individuals, and is not always present on both the sides of the sphenoid bone (Mazengenya and Ekpo, 2017). Many studies were conducted to evaluate the importance of this emissary vein passing through this foramen ,this provides a better understanding of the morphology of this particular structure that has significance in the spreading infections from extracranial origin into the skull and also in neurological techniques such as

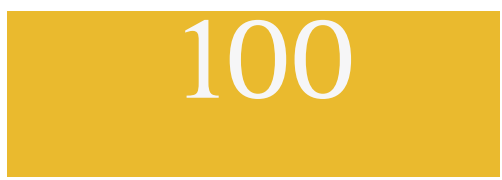


radio frequency(Chaisuksunt et al., 2012). Foramen innominatus is found between foramen spinosum and foramen ovale, this helps in the transmission of lesser superficial petrosal nerve, a very small tympanic branch of the glossopharyngeal and also several branches of the facial nerve .

Various studies are done on usual and unusual foramina present in the middle cranial fossa and its clinical importance (Paraskevas, Nitsa and Koutsouflianiotis, 2015), (Maina, Ducati and Lanzino, 2007). (Khairnar and Bhusari, 2013). (Prakash et al., 2019). From the previous studies we come to a conclusion that several studies were conducted on foramen ovale and foramen spinosum which are present in the middle cranial fossa but our study mainly focuses on unusual foramina such as foramen vesalius and foramen innominatus and its clinical significance.

Previously our department has published extensive research on various aspects of dentistry (Begum et al, 2017; Ganapathy, Kannan and Venugopalan, 2017; Jain, 2017a, 2017b; Ranganathan, Ganapathy and Jain, 2017; Ariga et al., 2018; Gupta, Ariga and Deogade, 2018; Anbu et al., 2019; Ashok and Ganapathy, 2019;
Duraisamy et al., 2019; Varghese, Ramesh and Veeraiyan, 2019), this vast research experience has inspired us to research about study of unusual foramina in middle cranial fossa in adult south indian dry skulls and its clinical significance.

\section{MATERIAL AND METHODS}

For the present study, 30 dry adult human cranial fossa of unknown sex from the Department of Anatomy, Saveetha Dental College and Hospitals, Chennai, India was used. Each skull was studied for the presence of foramen vesalius and foramen innominatus and the records were tabulated accordingly .

\section{RESULTS AND DISCUSSION}

Unilateral right foramen vesalius was present in 2 out of 30 skulls (6.7\%) . Bilateral foramina vesalius was present in 1 out of 30 skulls (3.3\%) (Figure 1). Unilateral right foramen innominatus was present in 3 out of 30 skulls $(10 \%)$. Unilateral left foramen innominatus was present in 1 out of 30 skulls(3.3\%) (Figure 2).Both the foramina were not present in 23 skulls out of 30 skulls (77\%).

Table 1. Incidence of Foramen Vesalius and Foramen Innominatus in 30 cranial cavity examined

\begin{tabular}{|l|c|c|c|c|c|c|}
\hline $\begin{array}{l}\text { Right unilateral } \\
\text { foramen } \\
\text { vesalius }\end{array}$ & $\begin{array}{c}\text { Left unilateral } \\
\text { foramen } \\
\text { vesalius }\end{array}$ & $\begin{array}{c}\text { Right unilateral } \\
\text { foramen } \\
\text { innominatus }\end{array}$ & $\begin{array}{c}\text { Left unilateral } \\
\text { foramen } \\
\text { innominatus }\end{array}$ & $\begin{array}{c}\text { Bilateral } \\
\text { foramina } \\
\text { vesalius }\end{array}$ & $\begin{array}{c}\text { Bilateral } \\
\text { foramina } \\
\text { innominatus }\end{array}$ & $\begin{array}{c}\text { Both the } \\
\text { foramina not } \\
\text { present }\end{array}$ \\
\hline $2 / 30$ & $0 / 30$ & $3 / 30$ & $1 / 30$ & $1 / 30$ & $0 / 30$ & $23 / 30$ \\
\hline
\end{tabular}

Figure 1: Red arrows shows bilateral foramen Vesalius

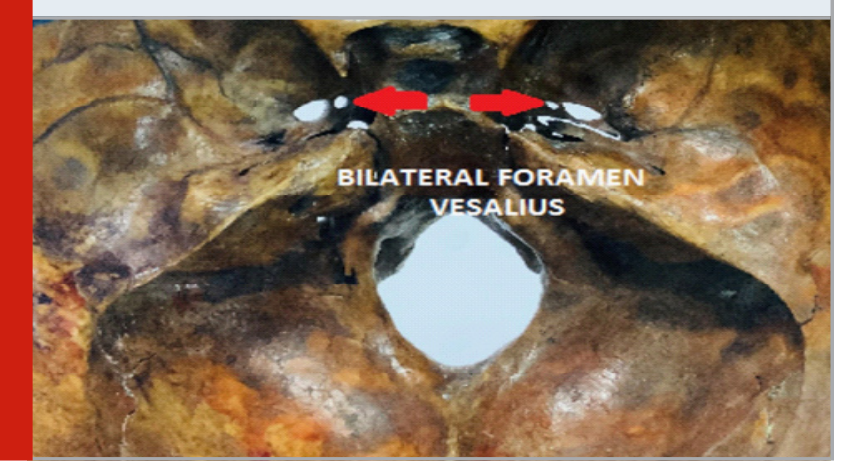

Foramen vesalius is an inconsistent foramen located between foramen rotundum and foramen ovale. In newborn's, the foramen is about $1.0 \mathrm{~mm}$ in length, in the adults at the right side about $2 \mathrm{~mm}$ in length and on the left side $1.4 \mathrm{~mm}$ in length. The width increases from 1.0 to $1.14 \mathrm{~mm}$ at the right side and from 1.0 to $1.3 \mathrm{~mm}$ at the left side (Lang, Maier and Schafhauser, 1984).

In most of the cases foramen vesalius is symmetrical in nature but in few cases it is asymmetrical, this is caused 101
Figure 2: Red arrow shows unilateral foramen Innominatus on Left side

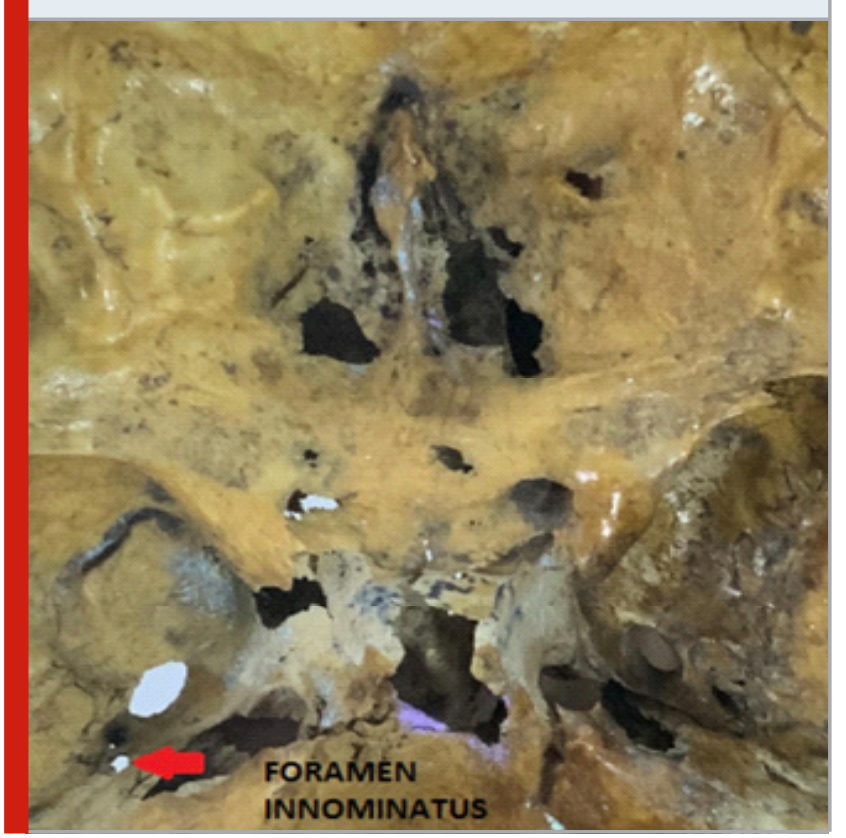


Table 2. Comparison of incidence of abnormal foramen in current and previous studies

\begin{tabular}{|l|c|c|c|c|}
\hline Author & $\begin{array}{c}\text { Year of } \\
\text { study }\end{array}$ & Incidence & Bilateral & Unilateral \\
\hline Gupta N et al & 2014 & $34 \%$ & $14 \%$ & $20 \%$ \\
\hline Raval et al & 2015 & $60 \%$ & $32 \%$ & $35 \%$ \\
\hline Nayak et al & 2018 & $30 \%$ & $20 \%$ & $10 \%$ \\
\hline Present study & 2020 & $23.3 \%$ & $3.3 \%$ & $20 \%$ \\
\hline
\end{tabular}

due to invasion by nasopharyngeal melanoma, a rare type of head and neck mucosal melanoma, angiofibroma which is a benign tumour that is made up of blood vessels and fibrous tissue, carotid -cavernous fistula with drainage through the emissary vein ais a result from an abnormal communication between the arterial and venous systems within the cavernous sinus in the skull or neurofibromatosis which is a genetic neurological disorder that can affect the brain, spinal cord, nerves and skin (Lanzieri et al., 1988) . Regarding the differences between the male and female gender, no remarkable differences were observed, although the occurrence of this foramen was more common in females compared to males (Gupta, Ray and Ghosh, 2005).

Nauma Hafeez et al states that the occurrence of foramen vesalius and foramen innominatus were 20\% and 13\% respectively (Hafeez and Thenmozhi, 2016). Neha Gupta et al , states that foramen vesalius was found to be present in 68 skulls out of which it was found bilaterally in 28 skulls and unilaterally in 40 skulls (Gupta $\mathrm{N}$ et al., 2014). Nayak et al, states that the foramen vesalius is a common anatomical variation and the incidence of the foramen vesalius was found to be 30\% ( $20 \%$ bilateral and 10\% unilateral) (Nayak et al., 2018) [Table 2]. The recognition of anatomical structures and their possible structures will be helpful to differentiate between normal from potentially abnormal structures during computed tomography and Magnetic resonance imaging.

\section{CONCLUSION}

In our study, the incidence of these foramina was 23.3\%, which is considerably lower than other previous studies. The exact cause of these variations that were observed in our study might be due to genetic, nutritional, environmental or other unknown reasons. The incidence of Foramen vesalius and Foramen innominatus were $10 \%$ and $13.3 \%$ respectively. Knowledge about these unusual foramina would be useful to neurosurgeons while conducting surgeries .

\section{ACKNOWLEDGEMENTS}

We acknowledge Department of Anatomy for allowing us to use bones from their collection for this study

Conflict of Interest: The author declares that there is no conflict of interest in the present study.

\section{REFERENCES}

Anbu, R. T. et al. (2019) 'Comparison of the Efficacy of Three Different Bone Regeneration Materials: An Animal Study', European journal of dentistry, 13(1), pp. 22-28.

Ariga, P. et al. (2018) 'Determination of Correlation of Width of Maxillary Anterior Teeth using Extraoral and Intraoral Factors in Indian Population: A Systematic Review', World Journal of Dentistry, 9(1), pp. 68-75.

Ashok, V. and Ganapathy, D. (2019) 'A geometrical method to classify face forms', Journal of oral biology and craniofacial research, 9(3), pp. 232-235.

Begum R, Ariga P, Ashish Jain'Evaluation of Corrosive Behavior of Four Nickel-chromium Alloys in Artificial Saliva by Cyclic Polarization Test:An in vitro Study' (2017) World Journal of Dentistry, 8(6), pp. 477-482.

Chaisuksunt, V. et al. (2012) 'Occurrence of the foramen of Vesalius and its morphometry relevant to clinical consideration', TheScientificWorldJournal, 2012, p. 817454.

Duraisamy, R. et al. (2019) 'Compatibility of Nonoriginal Abutments With Implants: Evaluation of Microgap at the Implant-Abutment Interface, With Original and Nonoriginal Abutments', Implant dentistry, 28(3), pp. 289-295.

Ganapathy, D. M., Kannan, A. and Venugopalan, S. (2017) 'Effect of Coated Surfaces influencing Screw Loosening in Implants: A Systematic Review and Meta-analysis', World Journal of Dentistry, 8(6), pp. 496-502.

Gupta N, Yadav, Thomas, Srivatsava. (2014) 'Incidence of Foramen Vesalius in Adult Human North Indian Crania', IOSR Journal of Dental and Medical Sciences, 13(5), pp. 34-38.

Gupta, N., Ray, B. and Ghosh, S. (2005) 'Anatomic characteristics of foramen vesalius', Kathmandu University medical journal , 3(2), pp. 155-158.

Gupta, P., Ariga, P. and Deogade, S. C. (2018) 'Effect of Monopoly-coating Agent on the Surface Roughness of a Tissue Conditioner Subjected to Cleansing and Disinfection: A Contact Profilometric Study', 
Contemporary clinical dentistry, 9(Suppl 1), pp. S122S126.

Hafeez, N. and Thenmozhi (2016) 'Accessory foramen in the middle cranial fossa', Research Journal of Pharmacy and Technology, 9(11), p. 1880.

Jain, A. R. (2017a) 'Clinical and Functional Outcomes of Implant Prostheses in Fibula Free Flaps', World Journal of Dentistry, 8(3), pp. 171-176.

Jain, A. R. (2017b) 'Prevalence of Partial Edentulousness and Treatment needs in Rural Population of South India', World Journal of Dentistry, 8(3), pp. 213-217. Khairnar, K. B. and Bhusari, P. A. (2013) 'An anatomical study on the foramen ovale and the foramen spinosum', Journal of clinical and diagnostic research: JCDR, 7(3), pp. 427-429.

Kumar, A., Sehgal, R. and Roy, T. S. (2016) 'A morphometric analysis and study of variations of foramina in the floor of the middle cranial fossa', Journal of the Anatomical Society of India, 65(2), pp. 143-147.

Lang, J., Maier, R. and Schafhauser, O. (1984) '[Postnatal enlargement of the foramina rotundum, ovale et spinosum and their topographical changes]', Anatomischer Anzeiger, 156(5), pp. 351-387.

Lanzieri, C. F. et al. (1988) 'The significance of asymmetry of the foramen of Vesalius', AJNR. American journal of neuroradiology, 9(6), pp. 1201-1204.

Maina, R., Ducati, A. and Lanzino, G. (2007) 'The middle cranial fossa: morphometric study and surgical considerations', Skull base: official journal of North American Skull Base Society ... [et al.], 17(6), pp.
395-403.

Mazengenya, P. and Ekpo, O. (2017) 'Unusual foramen in the middle cranial fossae of adult black South African skull specimens', Surgical and radiologic anatomy: SRA, 39(7), pp. 815-818.

Nayak, G. et al. (2018) 'ANATOMICAL STUDY OF FORAMEN VESALIUS', Journal of Evolution of Medical and Dental Sciences, 7(35), pp. 3847-3850.

Paraskevas, G., Nitsa, Z. and Koutsouflianiotis, K. (2015) 'Bilateral Osseous Interclinoid Bridges Associated with Foramina of Vesalius: A Case Report', Journal of clinical and diagnostic research: JCDR, 9(7), pp. AD03-4.

Prakash, K. G. et al. (2019) 'Morphometric and Anatomic Variations of Foramen Ovale in Human Skull and Its Clinical Importance', Asian journal of neurosurgery, 14(4), pp. 1134-1137.

Ranganathan, H., Ganapathy, D. M. and Jain, A. R. (2017) 'Cervical and Incisal Marginal Discrepancy in Ceramic Laminate Veneering Materials: A SEM Analysis', Contemporary clinical dentistry, 8(2), pp. 272-278.

Raval, B. B., Singh, P. R. and Rajguru, J. (2015) 'A morphologic and morphometric study of foramen vesalius in dry adult human skulls of gujarat region', Journal of clinical and diagnostic research: JCDR, 9(2), pp. AC04-7.

Varghese, S. S., Ramesh, A. and Veeraiyan, D. N. (2019) 'Blended Module-Based Teaching in Biostatistics and Research Methodology: A Retrospective Study with Postgraduate Dental Students', Journal of dental education, 83(4), pp. 445-450. 